\title{
ADAPTING DIGITAL BANKING SERVICES DURING COVID-19 PANDEMIC: A STUDY ON CUSTOMER EXPERIENCES IN SELECTED DISTRICT OF MAHARASHTRA STATE, INDIA
}

\author{
Dr. Shubhangee Ramaswamy \\ Professor, Sinhgad Institute of Management, and Computer Application, \\ Savitribai Phule Pune University, India \\ Dr. Rajeshree Khande \\ Associate Head, School of Computer Science, MIT-World Peace University, \\ Pune, India
}

\section{Dr. Yashwant S. Patil}

Associate Professor \& Head of Center, Information Technology, Vaikunth Mehta National Institute of Cooperative Management, Pune, India.

\section{Dr. Parag Kalkar}

Dean Faculty of Commerce and Management, Savitribai Phule Pune University, Maharashtra, India

\begin{abstract}
Introduction: Banks play a vital role for economic growth since their evolution. A bank is a financial institution which deals with monetary deposits, lending, and credits to the customers. In present landscape, banks and businesses are interconnected with each other. The increase in innovation in technologies and development of new solutions encourages banks to transform from traditional bank to e-bank. Rising number of banking institutes are moving toward digital platforms to deliver their services online because of increasing usage of smart phones and internet penetration across the world. Hence, rise in adoption of online and mobile banking platforms are positively impacting the adoption of Digital Banking Services (DBS) across the globe. During covid-19 outbreak the usage of digital banking services increased drastically in urban and rural area of selected region of Maharashtra State.

Methodology: In the present study efforts were made to understand the growth of digital banking services and related customer experience by means of collecting firsthand information from customers. The customer experience is studied on the basis of selected parameters like: trust on digital banking services (DBS), Preference towards nationalized, cooperative and private banks, widely used transaction type, Popular
\end{abstract}


Digital wallet platform for online payment, secured banking transaction, convenience of use, perceived benefits and disadvantages of digital banking services. On the other hand systematic approach to review the literature is adopted to study related trends.

Findings: Though there is increased usage of DBS during covid-19 outbreak and people have higher preference to use DBS still awareness, security concern, convenience of use and network connectivity remains major issues needs to be addressed. Superior customer experience means clarity and transparency, support for digital tools with which many customers are still unfamiliar in distress. Communication and quickly adoption of technology and situation plays crucial role. Implications: This study is useful for all the banks as an input to maximize their customer experience and strengthen their customer base at large. Banks would do well when they expand their digital infrastructure encompassing stability, security, availability and reliability of their digital services.

Keywords: Covid-19 Pandemic, Digital Banking Services (DBS), Customer Experience (CX), Nationalized Bank, Private and Cooperative Bank. Online Banking.

Cite this Article: Shubhangee Ramaswamy, Rajeshree Khande, Yashwant S. Patil and Parag Kalkar, Adapting Digital Banking Services during Covid-19 Pandemic: A Study on Customer Experiences in Selected District of Maharashtra State, India, International Journal of Electrical Engineering and Technology (IJEET), 12(5), 2021, pp.8-17. https://iaeme.com/Home/issue/IJEET?Volume=12\&Issue $=5$

\section{INTRODUCTION}

In a short period of time, COVID-19 has overwhelmed lives and livelihoods around the globe. For vulnerable individuals and the customer teams that serve them, it has also forced a rethinking of what customer care means. Suddenly, examinations of customer journeys and satisfaction metrics to inform what customers want have given way to an acute urgency to address what they need. Hand in hand with this perspective, four CX practices can frame shortterm responses, build resilience, and prepare customer-forward companies for success in the days after coronavirus. They are: focusing on care and connection; meeting customers where they are today; reimagining CX for a post-COVID-19 world; and building capabilities for a fast-changing environment (Rachel Diebner, Elizabeth Silliman, Kelly Ungerman, and Maxence Vancauwenberghe (April 2020).

In the context of COVID-19, banks can better serve customers in distress by enhancing support in the use of digital tools and new products and services. Banks can play an immediate role in slowing the spread of COVID-19 by helping customers make better use of existing digital and remote channels. And banks can help limit the impact of the likely downturn by building new experiences to help their customers manage debt, adjust budgets, and make full use of new government programs. In normal times, customer experience in banking is about making customers happy with the result that they are more loyal, use products more, and cost less to serve. In the context of COVID-19, superior customer experience means clarity and transparency, support for digital tools with which many customers are still unfamiliar, and new products and services for customers in distress. Banks can play a significant role in easing financial distress, so that customers can spend more energy on their families' and their own health and well-being (Eleanor Bensley, Shital Chheda, Robert Schiff, Daniel Stephens, and Nicole Zhou, April 2020). In times of crisis, customers' priorities change. 
Four actions can address immediate customer needs and prepare for the future.

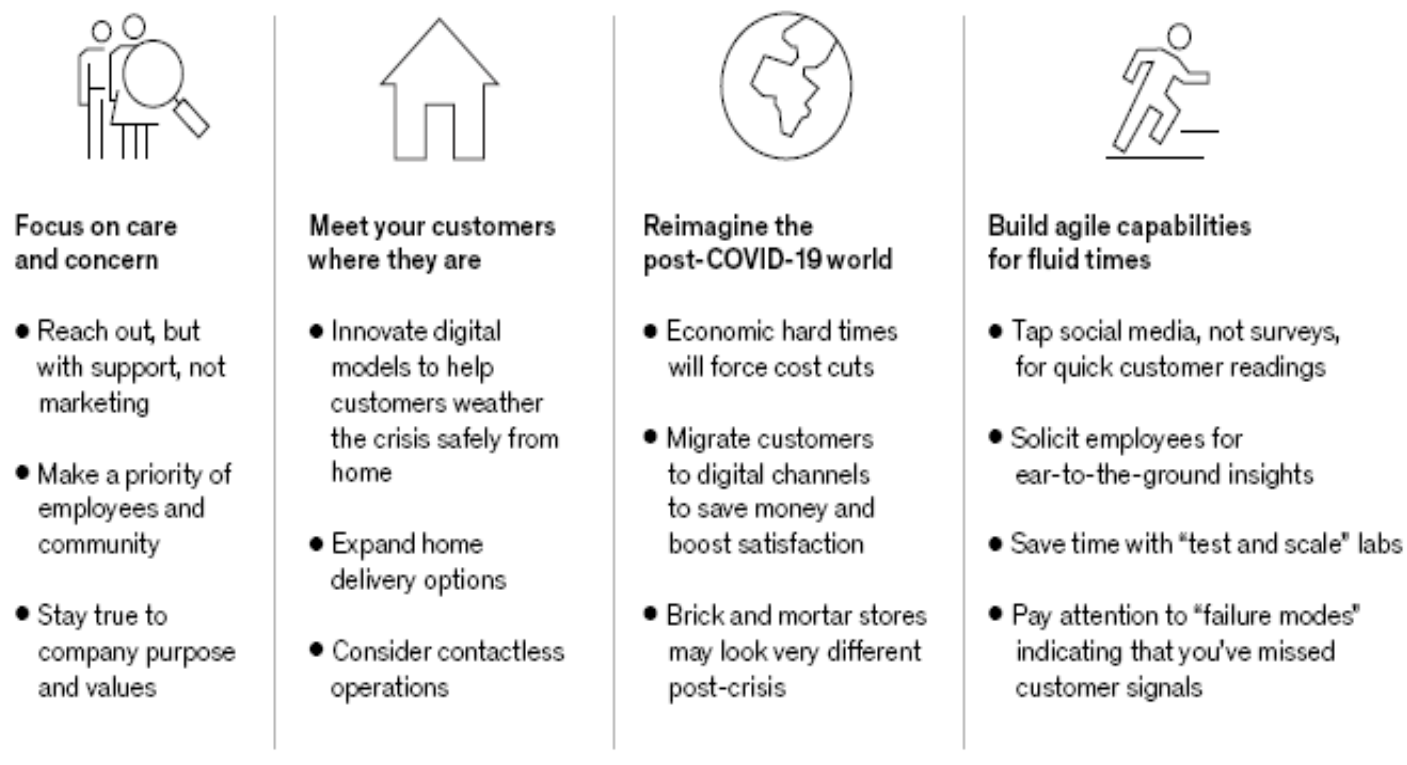

${ }^{1}$ Earned brand 2019, Edelman, edelman com.

Statement of Research Problem: Though the customer is techno savvy or otherwise covid19 outbreak acted as catalyst to increase the usage of digital banking services across the globe. An unavoidable consequence of the pandemic was the closure of some banks because customers adopted digital alternatives which they fail to offer. The reality is that this digital shift has laid the foundations to address the need for greater engagement with customers to improve their experience, which was already banks' top strategic priority, according to a recent report by the Economist Intelligence Unit (EIU).

\section{OBJECTIVE}

- To study the effect of covid-19 pandemic on Digital Banking Services

- To conduct customer experience survey regarding usage of Digital Banking Services during Pandemic in the selected rural and urban region on Maharashtra State, India

- To suggest best practices for Digital Banking Services to strengthen the customer base.

\section{LITERATURE REVIEW}

The global digital banking market registered revenue of nearly $\$ 803.8$ billion in 2018 and is anticipated to grow at a $10.0 \%$ CAGR, surpassing $\$ 1,702.4$ billion by 2026 . The market has witnessed a significant growth previously, but due to the unexpected COVID-19 outbreak, the market will witness additional growth in 2020, owing to the rising adoption of mobile payment solutions. This growth will be majorly driven by changing customer behavior, increasing focus of the people from visiting bank branches to online access of bank services. With the worldwide spread of COVID-19, the bank operations have been hampered. Borrowers and businesses have faced losses, there has been sluggish growth in sales, and decline in profits. On the other hand, this pandemic has been considered as an opportunity by some to launch

The covid-19 pandemic has brought digital wave across the globe. Almost all the sectors were forced to adopt technology to their best possible ability. When the coronavirus hit the 
world, banks reacted like every other sector, by focusing on adoption of technology and maintaining business continuity. The digital infrastructure played very important role in business continuity. To facilitate the shift to digital, many banks had to expand to new channels chat applications Most of those initiatives can be seen as reactive and short term, but are a step ahead in the right direction. The impact of COVID-19 on business and consumer behavior change is a topic of great importance for companies and financial industry around the world not only to take actions on short-term, but, even more important, to reconsider their strategy on medium and long term(Baicu, C.G., Gârdan, I. P., Gârdan, D.A., Epuran, G., (2020), The customer experience is increasingly shaped by technology giants, and banks know that their customers expect the same kind of seamless, contextual, compelling service from them. Earlier, the risk of frauds was considerably low, as banks transactions were considered secure due to PIN integrated with online authorization to authenticate the transactions. With increase in innovation in the fintech industry, fraudsters have been coming up with new frauds such as cyber-attacks and skimming, which hamper the market growth. Cyber-attacks are increasing nowadays, and becoming one of the major threats for banks across the globe. In addition, online banking sites and mobile apps are designed to offer security, and banks are continuously updated the sites. However, no system is completely foolproof and can be hacked at any point of time, resulting into risk of identity theft, stolen login credentials, and others.As covid-19 accelerates the take-up of digital banking services, banks have a unique opportunity to address two of the biggest problems facing the sector: customer satisfaction and trust. Banks that have supported their customers during the pandemic have an opportunity to change the relationship with their clients to build deeper trust, which is the most valuable asset for banks, old or new.

The financial institution should focus on providing value to their customer, help them achieve their financial goal such as buying a house, and in this instance view them as a home buyer not just a borrower. This involves a different approach; it means reinventing processes and unifying the bank around the customer. With the right digital tools to analyze risk, it's possible today for a mortgage application to be approved in minutes. Yet too many financial institutions still don't offer even this and open banking can deliver so much more. Banks should be aiming to integrate with third parties to provide a suite of services - not only a mortgage, but also help with finding a property to buy, home insurance, transferring utility accounts to the new address, and so on.

In the aftermath of the covid-19 pandemic, many industries want to 'build back better', rather than return to business as it was before. Banks should do the same. Their customers have been forced by circumstances to embrace digital banking. It's up to the banks to compete on experience making it as personal, engaging and rewarding as it can be. Get that right and banks can truly turn customers into partners.

In these unsettling times, CIOs who are quick to adapt to a mobile-first approach for their services will be the first to see improvement in their ROIs and earn some trust from their consumers. With the foray of new technologies and financial tech institutions slicing into the banking pie and more importantly, with the uncertainty of global events, the banking industry needs to quickly adapt and look towards elevating the customer experience and also finding a way to reassure their customers to retain and engage them remotely. By putting the customer at the core of their business strategy, banks can still find a way to add some stability to their businesses. According to a Study by Kantar, "Financial institutions that lead in customer experience $(\mathrm{CX})$ have a higher recommendation rate, a higher share of deposits, and a greater likelihood that customers will increase their portfolio of new products and services from their bank. While financial institutions that let their customer experience decline, risk losing up to $12.5 \%$ of their share of deposits." 
The 'Leaders' that are quick to adapt to a mobile first approach for their services will be the first to see improvement in their ROIs and earn some trust from their consumers. Automating processes and improving customer communication by implementing new age digital solutions should be the way forward for banks moving on. This will also help the industry better use existing resources, reduce paperwork and improve time to market for several of their services while offering consumers the convenience of banking on the go from their mobile phones or tablet. Besides net banking and mobile apps, banks need to use preferred channels of communication such as Social media, Instant Apps or Progressive Web Apps and OTT messaging apps to reach out to their customers considering the amount of time consumers spend on such channels.

Given the far-reaching impact that COVID-19 will have on the payments space, TCS believe that banks would do well to expand access to digital touch points underpinned by stability, security, availability, and reliability in the immediate term. Accordingly payment firms with strong fundamentals and focus on digital payments are most likely to emerge as leaders in the post-COVID era. As the industry navigates through the pandemic, payment players will need to define their response across four phases that may overlap: Immediate-term: ensure availability and stability of the IT systems as continuous access to immediate funds is key. Short-term: identify the most frequently used services, analyze consumer spend behavior, and design an action plan to extend services over the right digital channels. Medium-term: focus on expansion of digital services and interactions to enhance customer affinity; leverage the power of open banking to expand the charter for digital services and innovations. Long-term: focus on strategic business continuity improvements and supporting a digital-only organization strategy (Tata Consultancy Services Limited, 2020). A study by Qureshi, Zafar, \& Khan (2017) found that one in every two Pakistanis used internet banking, suggesting that there are some risk averse people in society, and this extends beyond Pakistan (Mostafa and Eneizan, 2018; Siyal, Donghong, Umrani, Siyal, \& Bhand, 2019).

\section{DATA ANALYSIS AND INTERPRETATION}

Table 1 Demographics profile of respondents

\begin{tabular}{|c|c|c|}
\hline Profile of Respondents & $\begin{array}{c}\text { No. of } \\
\text { Respondent }\end{array}$ & Percentage (\%) \\
\hline \multicolumn{3}{|l|}{ Gender } \\
\hline Female & 34 & 33.3 \\
\hline Male & 68 & 66.7 \\
\hline \multicolumn{3}{|l|}{ Age } \\
\hline 21-30 year & 49 & 48 \\
\hline $31-40$ years & 26 & 25.5 \\
\hline $41-50$ years & 14 & 13.7 \\
\hline 51 years $\&$ above & 13 & 12.7 \\
\hline \multicolumn{3}{|l|}{ Education Qualification } \\
\hline Under Graduate & 24 & 23.5 \\
\hline Graduate & 30 & 29.4 \\
\hline Post Graduate & 41 & 40.2 \\
\hline Ph.D & 7 & 4.9 \\
\hline \multicolumn{3}{|l|}{ Area } \\
\hline Urban & 71 & 69.6 \\
\hline Rural & 31 & 30.4 \\
\hline
\end{tabular}




\begin{tabular}{|l|c|c|}
\hline \multicolumn{3}{|l|}{ Occupation } \\
\hline Government Employee & 10 & 9.81 \\
\hline Private Employee & 45 & 44.11 \\
\hline Self Employed /Business & 8 & 7.84 \\
\hline Farmer & 2 & 1.96 \\
\hline Student & 36 & 35.29 \\
\hline Housewife & 2 & 1.96 \\
\hline
\end{tabular}

In the present study demographic composition of respondents consist of male and females from Maharashtra State from both rural and urban area having the age group 21 years and above. Majority were working professional either in private or government sector.

Usage of digital banking services during COVID-19 outbreak

Table 2

\begin{tabular}{|l|c|c|}
\hline \multicolumn{1}{|c|}{ Use of DBS } & No. of Respondent & Percentage (\%) \\
\hline Yes & 98 & 96.07 \\
\hline No & 4 & 3.92 \\
\hline
\end{tabular}

Usage of digital banking services during COVID-19 outbreak

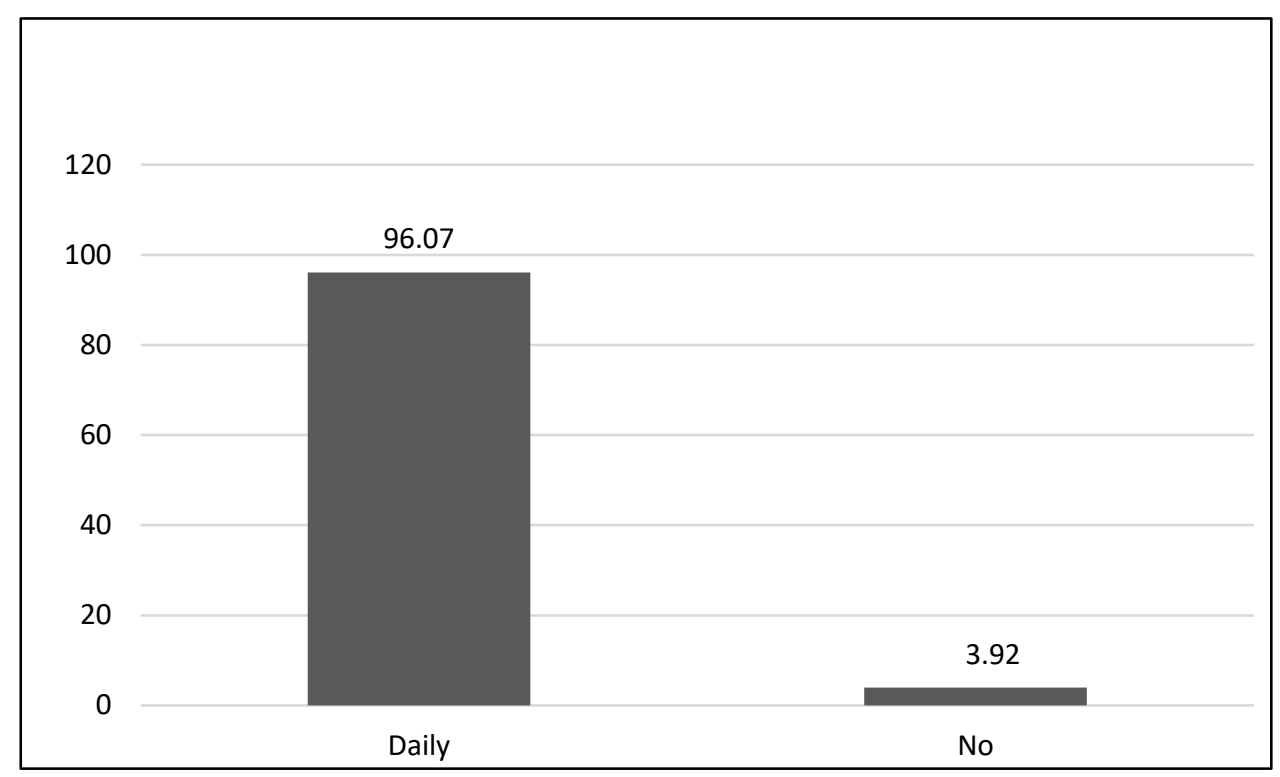

Figure 1

Frequency of usage of digital banking services

Table 3

\begin{tabular}{|l|c|c|}
\hline $\begin{array}{c}\text { Frequency of usage of } \\
\text { digital banking services }\end{array}$ & No. of Respondent & Percentage (\%) \\
\hline Daily & 25 & 24.51 \\
\hline 1-2 times in a week & 42 & 41.18 \\
\hline 3-4 times in month & 42 & 41.18 \\
\hline 5 times and more in month & 23 & 22.55 \\
\hline
\end{tabular}


Adapting Digital Banking Services during Covid-19 Pandemic: A Study on Customer Experiences in Selected District of Maharashtra State, India

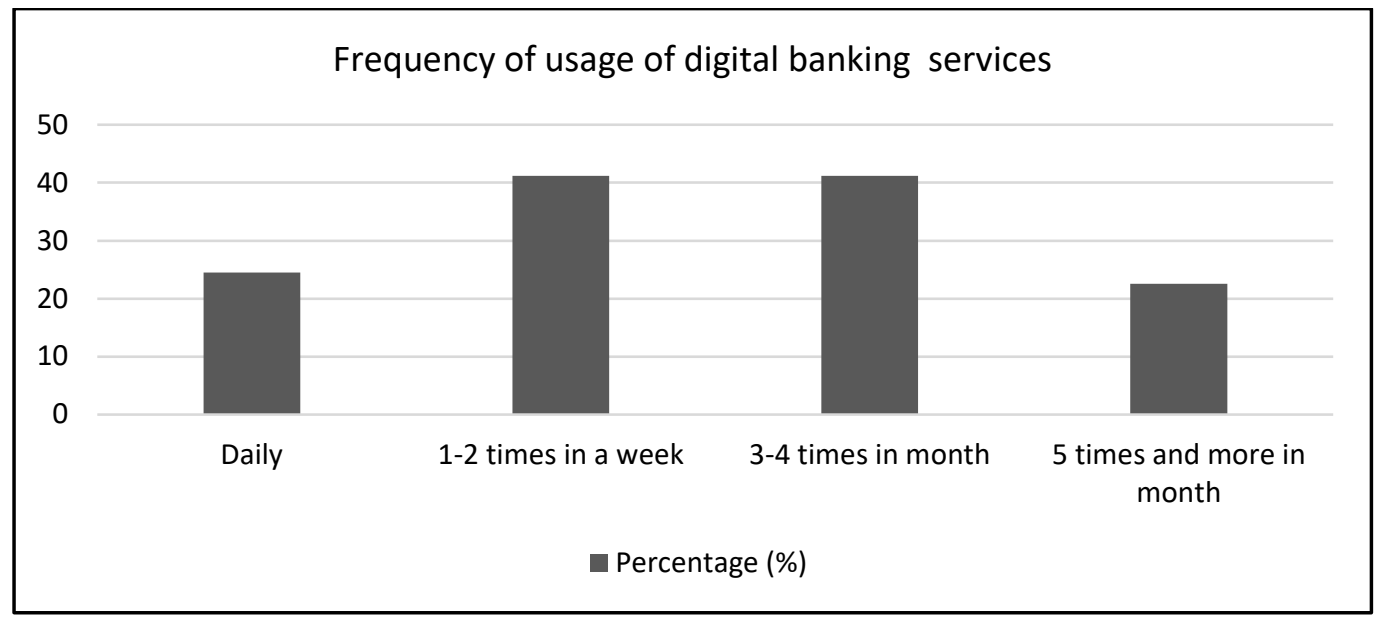

Figure 2

- Frequency of different types of digital banking services availed by customer

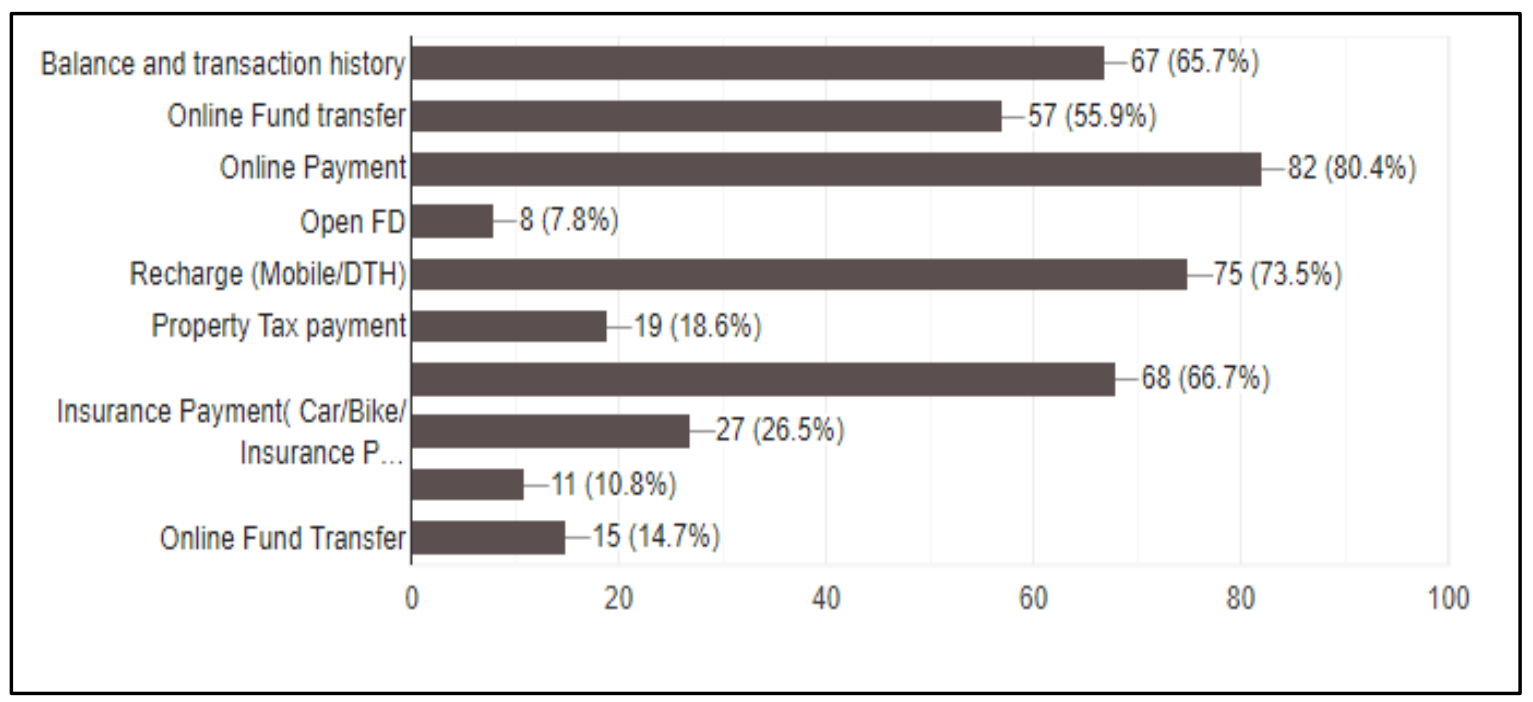

Figure 3

- $\quad$ Most used UPI Payment Apps

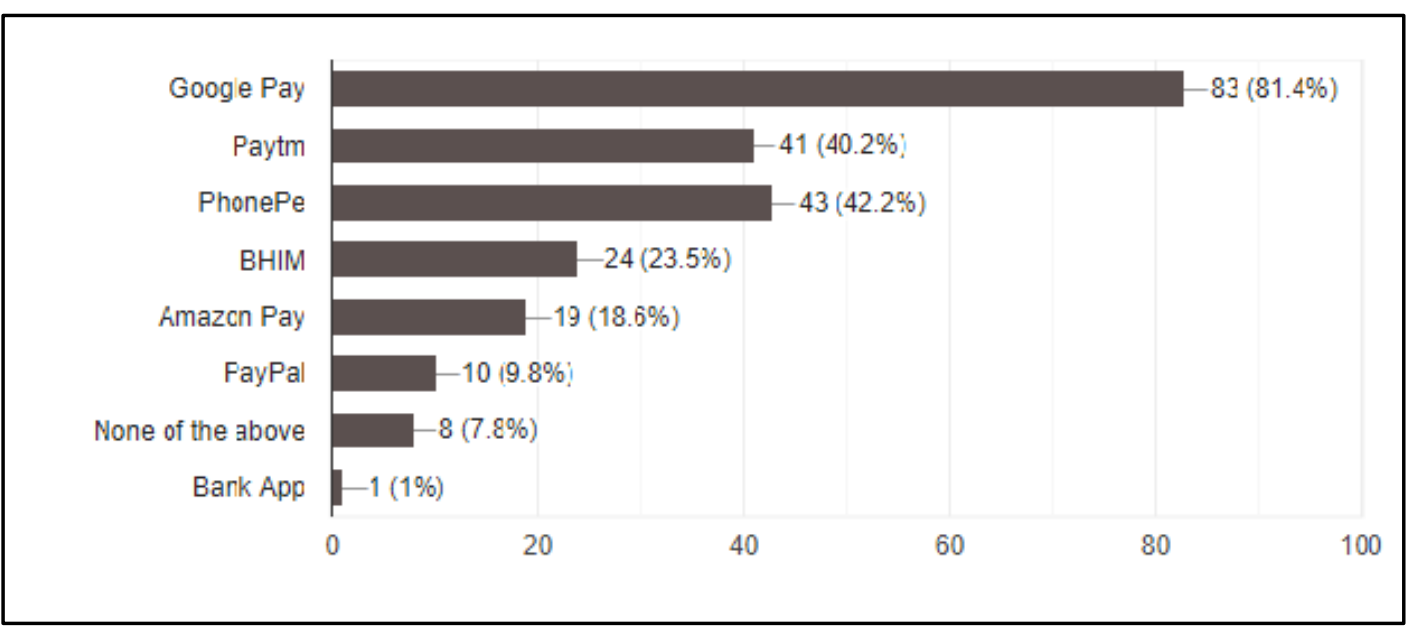

Figure 4 
- Benefits of using digital banking services

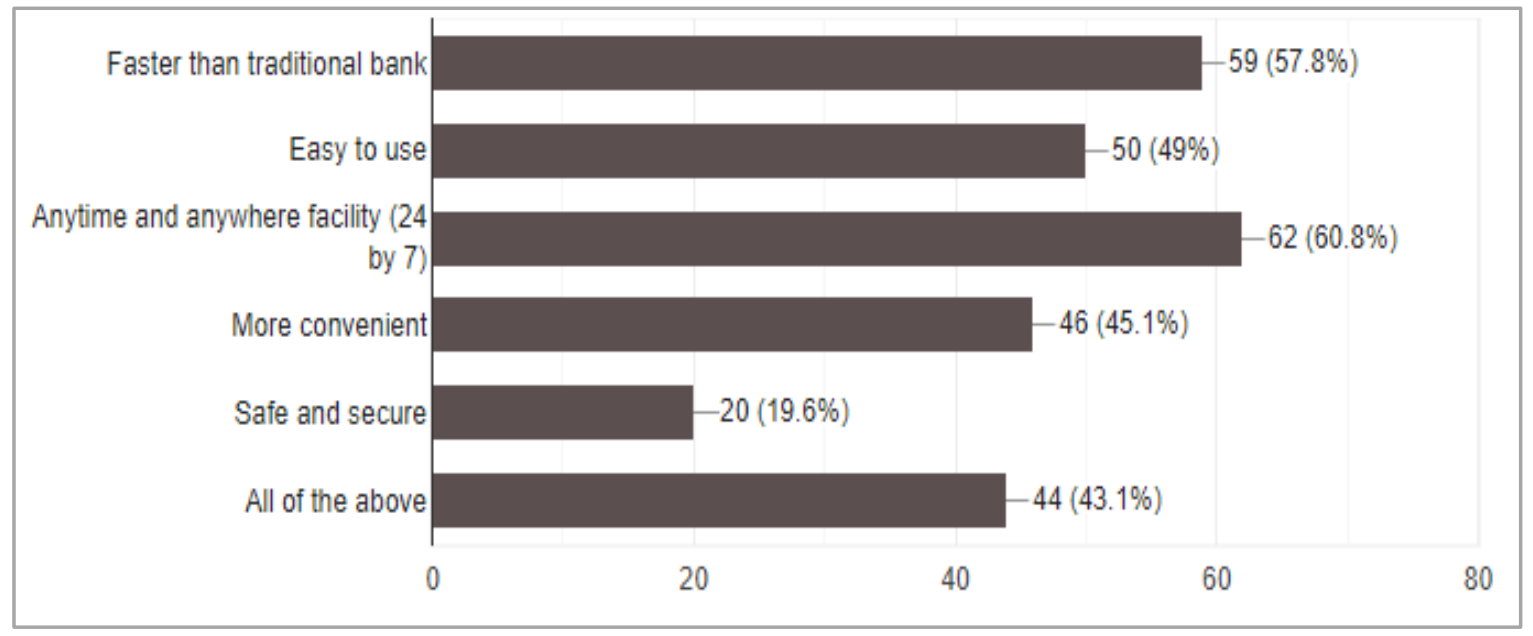

Figure 5

- Problems faced while using digital banking services during COVID-19 pandamic

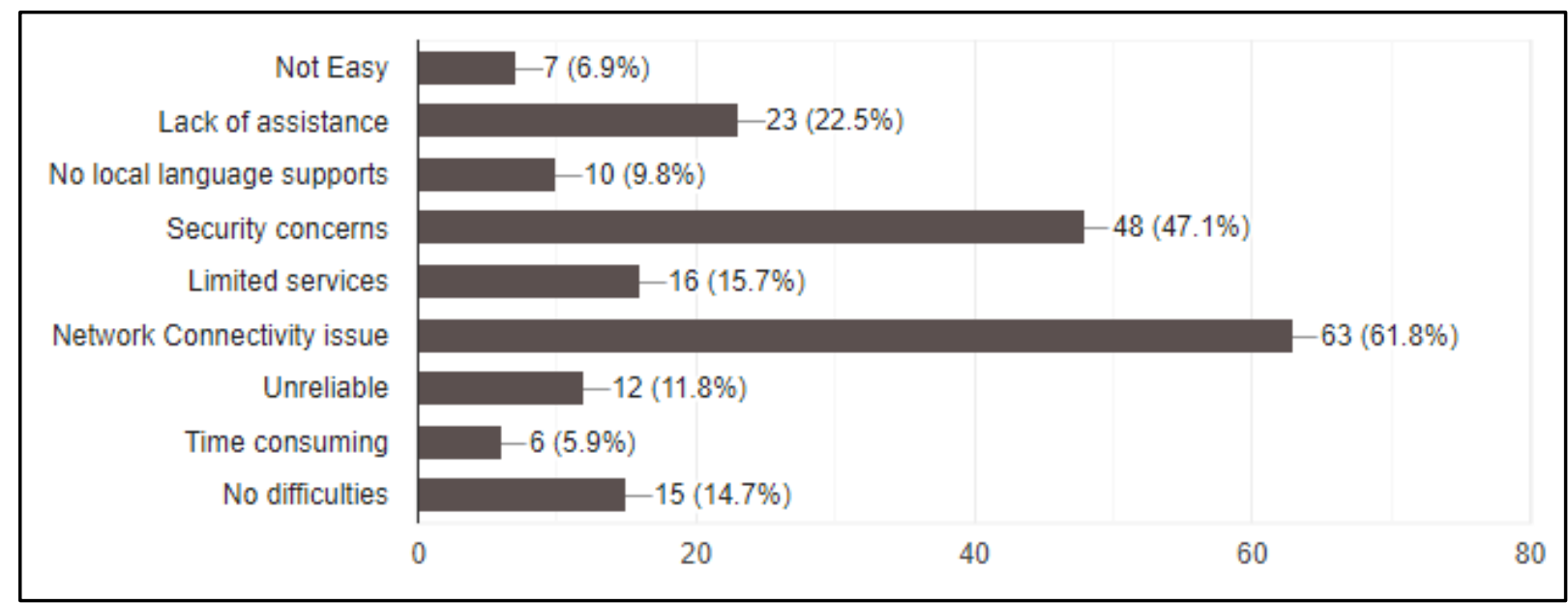

Figure 6

- Overall customer perception on availing digital banking services during pandemic COVID-19 outbreak

Table 4

\begin{tabular}{|l|c|c|}
\hline $\begin{array}{c}\text { Overall perception } \\
\text { on availing digital } \\
\text { banking services }\end{array}$ & $\begin{array}{c}\text { No. of } \\
\text { Respondent }\end{array}$ & Percentage (\%) \\
\hline Excellent & 27 & 26.47 \\
\hline Very Good & 43 & 42.16 \\
\hline Good & 29 & 28.43 \\
\hline Poor & 3 & 2.94 \\
\hline
\end{tabular}


Adapting Digital Banking Services during Covid-19 Pandemic: A Study on Customer Experiences in Selected District of Maharashtra State, India

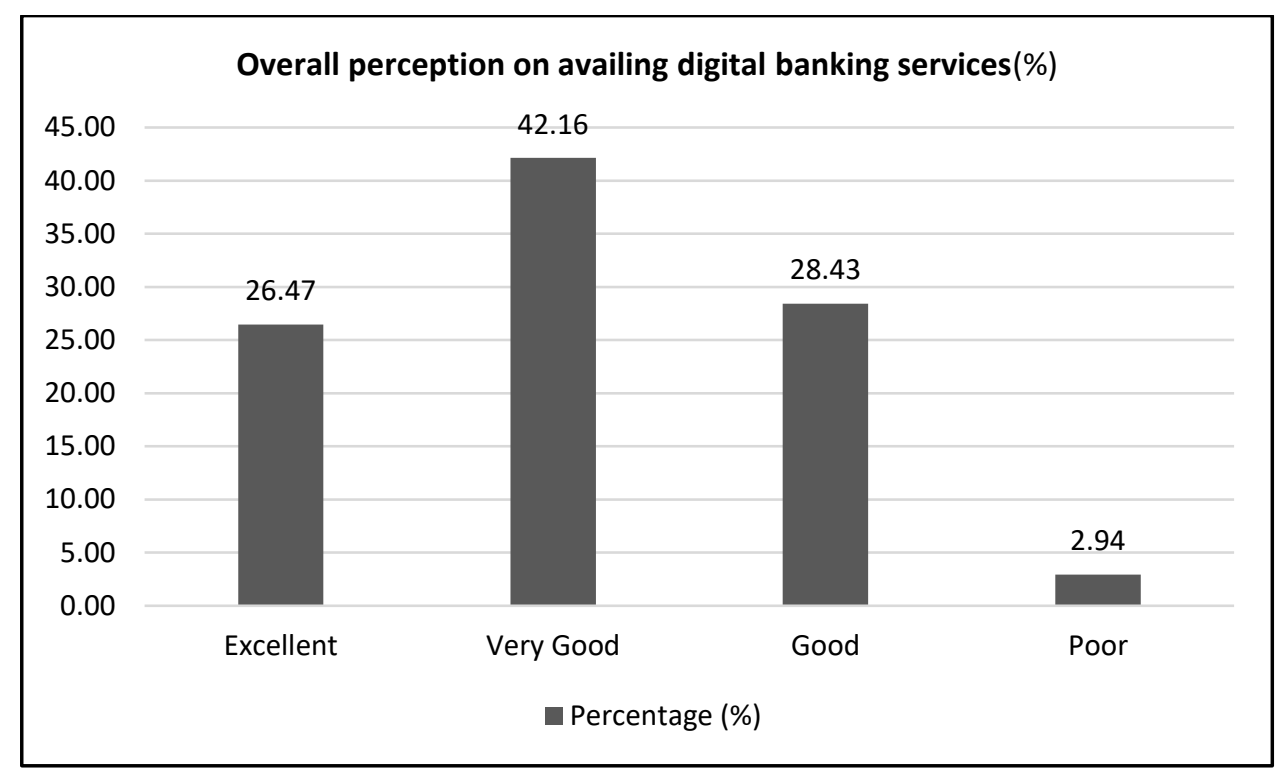

Figure 7

\section{FINDINGS AND DISCUSSION}

- As Covid-19 impacts the global economy, it will still be crucial for most organizations to ensure business continuity. Communication and quickly adapting to the situation will play a key role in ensuring this goal is met. Adopting of technology will play a crucial role in ensuring business continuity especially in banking sector.

- Digital banking market witnessed significant growth in the year 2020 will continue its growth even after the control of the pandemic situation.

- The customer experience is studied on the basis of selected parameters like: Trust on DBS, Preference towards nationalized, cooperative and private banks, Major usage of DBS for type of transaction, Popular Digital wallet platform for online payment, Secured Banking Transaction, Convenience of Use, Perceived benefits and Disadvantages of DBS.

- Though there is increased usage of DBS during covid-19 outbreak and people have higher preference to use DBS still awareness, security concern, convenience of use and network connectivity remains major issues needs to be addressed.

- In normal times, customer experience in banking is about making customers happy, in the context of COVID-19, superior customer experience means clarity and transparency, support for digital tools with which many customers are still unfamiliar in distress.

- Banks to overcome these obstacles during corona virus pandemic must empathize with their customers and support to meet their individual needs like retailer and telecoms companies do when a customer is unhappy with the standard offering. Banks can use AI technology and advanced analytics to approach their customers with personalized offers.

- Following are some of the suggestions for quickly adapting to remote world 1) Virtual assistants on WhatsApp or SMS 2) Live Chat for additional customer support 3) Marketing automation platform that can also be remotely operated from anywhere to track Big Data in real-time and help to send notifications and special offers for upselling and cross-selling services. 


\section{SCOPE FOR FURTHER RESEARCH}

Specific study among the nationalized, cooperative and private bank can be conducted to set the benchmark. Even comparative study among top three players in every segment can be conducted to understand their best practices.

\section{CONCLUSION}

Banks are significantly making continuous improvements in banking technologies to develop enhanced security in transactions. Banks need to implement an event-driven technology architecture to make every interaction smart and contextual. Focusing on the customer experience is the winning strategy during and post crisis.

\section{REFERENCES}

[1] Baicu, C.G., Gârdan, I. P., Gârdan, D.A., Epuran, G., (2020), "The impact of COVID-19 on consumer behavior in retail banking. Evidence from Romania", Management \& Marketing. Challenges for the Knowledge Society, Vol. 15, No. Special Issue, pp. 534-556, DOI: 10.2478/mmcks-2020-0031.

[2] Eleanor Bensley, Shital Chheda, Robert Schiff, Daniel Stephens, and Nicole Zhou (April 2020) Remaking banking customer experience in response to coronavirus, McKinsey and Company.

[3] Joaquin De Valenzuela Muley SVP \& Global Infinity Business Line Director Temenos (2020), Catalyst for change - How covid is driving banks to improve customer experience Report abuse.

[4] Mostafa, A. A. N., \& Eneizan, B. (2018). Factors Affecting Acceptance of Mobile Banking in Developing Countries. International Journal of Academic Research in Business and Social Sciences, 8(1), 340- 351.

[5] Rachel Diebner, Elizabeth Silliman, Kelly Ungerman, and MaxenceVancauwenberghe (April 2020) Adapting customer experience in the time of coronavirus McKinsey and Company.

[6] Tata Consultancy Services Limited (2020), Preparing for the Post COVID-19 World: Implications for Global Payments, Retrieved From: https://www.tcs.com/bankingfinancial-services.

[7] Tricia Moulton, Paul Andrew Bourne, Desron Graham, Ricard Jarrett, Mark Edwards, Vincent M.S. Peterkin, Carl Beckford, Marjorie Charles (2020), Online Banking among.

[8] Jamaicans during the 2020 COVID-19 Pandemic, The Corporate International, Vol. 4, Issue 2 - 2020, ISSN: 2581-6438 @ Eureka

[9] U.S. Embassy in Jamaica. (2020, August 7). Covid-19: Information-Jamaica. Kingston: U.S. Embassy. Retrieved from https://jm.usembassy.gov/covid-19-informationjamaica/, accessed August 26, 2020.

[10] https://www.researchdive.com/covid-19-insights/255/digital-banking-system-market

[11] https://newsroom.accenture.com/news/rapid-shift-to-digital-banking-during-covid-19accelerating- erosion-in-consumer-trust-accenture-report-finds.htm

[12] https://cio.economictimes.indiatimes.com/news/strategy-and-management/digitalbanking-in-the-times-of-a-covid-19-epidemic/75007525 - By Deepak Goyal

[13] https://www.worldfinanceinforms.com/trends/impact-analysis-of-covid-19-on-digitalbanking-market/Impact Analysis of Covid-19 on Digital Banking Market. Global Opportunity Analysis and Industry Forecast, 2019-2026. 